\title{
Vareanalyse
}

\section{Bemerkninger om en artikkel av H.-G. Backhaus}

\section{Jørgen Sandemose}

I en artikkel om det logiske og det historiske felt i vareanalysen (Kurasje nr. 27/28) vil H.-G. Backhaus gi et bidrag til forståelse av Marx' stilling til Hegels dialektikk. ${ }^{1}$ Til tross for at artikkelen inneholder en rekke svært viktige påpekninger og en interessant drøfting, kommer den etter vår oppfatning på enkelte måter til kort. I noen henseender kommer Backhaus fram til standpunkter som er vanskelige å forsvare, fordi han ikke godt nok utvikler det dialektikk-begrepet som stammer fra Hegel. Følgen er blant annet at han ikke ser den avgjørende enhet mellom Hegels og Marx' metoder, og dette fører i sin tur til at han heller ikke kan klargjøre hvor og hvordan Marx' metode virkelig bryter med Hegels. Samtidig får han store problemer med å forklare hva han egentlig mener med »det logiske«, for han begrenser seg i stor grad til bruk av kategorier som verken Marx eller Hegel ville kalle logiske $i$ ordets virkeligste betydning.

\section{Innledende bemerkninger om metode og filosofihistorie}

Backhaus' klareste formulering av sitt metodologiske »program « for tolkningen av Marx' vareanalyse er vel at »de begrebslige midler til denne værdi- og pengeteori, der er utarbejdet som værdiformanalyse, udgøres af læren om væsen og fremtrædelse « (Q 140).

Dette synspunktet utreder han i et eget metodologisk avsnitt (Q 134137). Det er ikke uten videre uriktig. Det dekker en viktig dimensjon i

1. Jfr. Hans-Georg Backhaus: »Om forholdet mellem det »logiske« og det »historiske« i Marx' kritik af den politiske $\varnothing$ konomi «, Kurasje 27/28, s. 117. I resten av denne artikkelen tar vi de fleste referanser til andre forfatteres verker inn i paranteser i teksten. For oversiktens skyld bruker vi noen av de samme forkortelser som Kurasje-redaksjonen anvendte i redigeringen av Backhaus' artikkel. De er:

MEW = Marx/Engels: Werke, Berlin $1962 \mathrm{ff}$.

K 1 = K. Marx: Das Kapital, bd. I (- MEW bd. 23).

$\mathrm{E}=$ Første opplags versjon (1867) av varekapitlet i Das Kapital. Vi refererer til sidetallene i Marx \& Engels: Studienausgabe, Frankfurt am Main 1966.

Wf = K. Marx: »Die Wertform«. Appendiks (1867) til E. Vi refererer til sidetallene i Marx/Engels: Kleine ökonomische Schriften, Berlin 1955.

$\mathrm{Z}=\mathrm{K}$. Marx: Zur Kritik der politischen Ökonomie, 1859 (-MEW bd. 13)

For $\emptyset$ vrig bruker vi følgende forkortelser:

$\mathrm{Q}=$ Backhaus' artikkel, nevnt ovenfor.

L 2 = G.W.F. Hegel: Wissenschaft der Logik, bd. II, Frankfurt am Main 1970. 
Marx' kritikk av de økonomiske kategorier generelt og av varen spesielt. Men det dekker ikke tilnærmelsesvis alle dimensjoner, og det treffer ikke det som er den overordnede angrepsvinkel i vareanalysen i Kapitalen - uansett hvilken utgave eller hvilket opplag en tenker på.

Vareanalysen er i eminent forstand en logisk analyse. Den dreier seg om dialektiske begrepsbestemmelser, om kategorier som skal bygge opp $\mathrm{Ka}$ pitalen som begrep. Kategorier som »vesen «, »framtredelse « (»Wesen«, »Erscheinung «, som det heter hos Hegel og Marx), »likhet«, »liksetting «, »virkeliggjøringsform «, »identitet «, »ikkeidentitet «, »differens « (som alle benyttes flittig i vareanalysen av Marx og Backhaus) er f.eks. ikke i streng forstand begrepsmessige hos Hegel, en tenker som i følge Backhaus har utviklet de »almene bevægelsesformer « som Marx ville føre sin analyse tilbake til (Q 117). At de åpenbart heller ikke er det i Marx’ oppfatning av dialektisk begrepsutvikling, skal vi komme tilbake til om et $\varnothing y e b l i k k$. Først er det imidlertid nødvendig å se noe nærmere på deres plass hos Hegel. Vi holder oss til hans Logikkens vitenskap, da det er hans begrep om det logiske felt som skal behandles.

Slike kategorier er i følge Hegel refleksjonsbestemmelser. De er selvfølgelig begreper, men de utvikles ikke i læren om begrepet. De er begreper om refleksjonen og om de former refleksjonen umiddelbart må forstås gjennom. Og refleksjonslæren er for Hegel et forstadium til begrepslæren, til læren om begrepet om begrepet. Denne teorien om begreps-begrepet danner så kvintessensen av hans egen filosofi, det aspekt ved den som - i følge ham selv - hever den opp over tidligere tenkning. Hans lære om tankenivåene forut for begrepsbegrepet, f.eks. refleksjonen, er derfor samtidig en framstilling av den tidligere filosofis standpunkter. Læren om refleksjonen, som utgjør den midterste av de tre bøkene i Logikkens vitenskap, er også en kritikk av den borgerlige filosofi i nytiden fra og med Böhme, Bacon og Descartes. Den viktigste eksponent for »refleksjonsfilosofien« er Kant.

Hva er karakteristisk for »refleksjonsfilosofien «? Først og fremst, mener Hegel, at den deler verden i to uten å ha midler til å lege dette bruddet igjen. Den er u-menneskelig, den stenger mennesket ute fra den ytre verden. Samtidig som dens talsmenn - som er mennesker som oss andre - lar den ytre verden bli underkastet et bestemt kausalt-mekanistisk prinsipp, lar den mennesket bli underkastet denne verden. Hegel mener at Kants filosofi aldri kommer ut av en slik motsetning, og at hans fors $\varnothing \mathrm{k}$ på å oppheve motsetningen ved »praktisk « filosofi egentlig bare reproduserer den.

Kant blir en typisk representant for refleksjonsfilosofien fordi han radikalt skiller menneskets erkjennelsesevne fra den ytre verden, fra det han 
kaller »Tingen i seg selv «. Denne toheten kan han umulig komme ut av, for han vil, som Hegel sier, liksom lære å svømme uten å gå i vannet. Hvilket er utlagt: Han vil ikke godta noen utsagn om den faktiske erkjennelsen før han har forsikret seg om hva erkjennelsen evner. Han vil først bestemme evnens struktur, og ut fra dette vil han bestemme hva som kan foregå når evnen brukes. Med marxistiske uttrykk kan en si at Kants filosofi er en åndelig gjenspeiling (eller bedre: foregripelse) av en social situasjon hvor de virkelige subjektene, arbeiderne, er blitt atskilt fra produksjonsmidlene, slik at de står ribbet tilbake hinsides naturens og samfunnets goder, overlatt til seg selv: De teller bare som en arbeidskraft eller en arbeidsevne, den er deres eneste eiendom (og den må de selge).

Hegel vil - uten å opphøre med å være borgerlig filosof - oppheve toheten i »refleksjonsfilosofien«, og det gjør han blant annet ved å lage et begrep om et teleologisk middel som skyves inn mellom menneske og ytre natur. I sin lære om begrepets begrep forstår han mennesket som et ledd i en trehet, ikke lenger i en tohet. Menneskene kan nå fram til en enhet med seg selv og alt annet ved å forbinde seg med sin omverden som med sine produksjonsmidler igjen. Hegels teori om begrepsbegrepet, fra dets spede begynnelse i domsformene (alle begrepers første »framtredelsesform «) til framstillingen av den idealistiske »absolutte idé«, er derfor en lære om at virkelighetens struktur er tredelt, uansett om den gir seg ut for å være todelt. Hvis den framstår som todelt, er det på grunn av en spesiell dynamikk innenfor det tredelte, eller rettere sagt innenfor det tre-enige.

Hegel mener at det er umulig å begripe noe så lenge en rett og slett er henvist til en tohet. Med bare to elementer finnes det ikke noen entydig metode til å bestemme elementene - verken ved hverandre eller hver for seg. Først når et tredje element dukker opp, kan to elementer unders $\varnothing$ kes $\mathrm{i}$ forhold til en felles (kvalitativ eller kvantitativ) målestokk. Veien mellom dem blir entydig: Den går gjennom et bestemt Tredje.

Hegel kaller den forutgående filosofi i nytiden for refleksjonsfilosofi fordi den tohet den står for, begrenser erkjennelsen til speilinger, reflekser og skyggespill. Erkjennelsen er henvist til to elementers »refleksjon« i hverandre, altså deres gjensidige »skinning « (Scheinen), uten noe håndgripelig Tredje. Verden blir en slags skinnverden, hvor konkrete relasjoner bare viser seg som »Er-scheinungen «.

Men Hegel skal jo ikke rett og slett bare beskrive denne cartesianskkantianske verden. Han skal kritisere den, vise at den er falsk og sann samtidig, at den er et uttryk for noe tilgrunnliggende, at »skinnet « altså ikke lar seg tenke uten et »vesen«. I tanken om Vesenet innvarsles begrepet om Begrepet, Vesenets og Skinnets opphevelse i en høyere metodisk form. Hegels refleksjonslære, annen bok i Logikkens vitenskap, heter der- 
for »Læren om Vesenet«. Og den er refleksjonslogikk, for den viser det sted hvor refleksjonstenkningen logisk hører hjemme.

\section{Det enkle verdiuttryk: kategorisk og hypotetisk form}

Hvordan kan en i praksis finne skillet mellom tohet og treenighet i en slik dialektisk tilnærmingsmåte? La oss se hvilke svar vi kan få ut av vareanalysen og Marx' undersøkelse av verdiens form. Denne analysen foregår ikke ut fra en refleksjonslogisk ramme, slik nærmest hele den dialektisk orienterte kommentarlitteraturen forestiller seg. Den foregår tvert om som en framstilling av en nødvendig dialektisk begrepssammenheng.

La oss få dette klart ved å ta utgangspunkt i den »enkle, individuelle eller tilfeldige verdiform «, som Marx eksemplifiserer med uttrykket 20 alen lerret $=1$ frakk, eller 20 alen lerret er 1 frakk verdt, dvs. med utsagnet

»20 alen lerret er verdt 1 frakk.«

For å se hva slags dom som her uttrykkes, bør vi være klar over det ofte oversette faktum at Marx skilte mellom to situasjoner i formutviklingen av det enkle verdiuttrykk. Skillet er gjort klarest i »Die Wertform « fra 1867 . $^{2}$ Verdiuttrykkets grunnlag er på den ene siden et likhetsforhold: »Basis for uttrykket... er i virkeligheten: lerret $=$ frakk, noe som uttrykt i ord bare betyr: varearten frakk er av lik natur, lik substans med varearten lerret, som er forskjellig fra den selv« (Wf 265).

Hva betyr disse »ord «, hva betyr det at ikke bare to »forskjellige« rett og slett, men to forskjellige »arter«, er satt like i samme »substans«? Hva betyr det at likheten dem i mellom er av substansiell natur? Uttrykt i terminologien fra begrepslæren ikke bare hos Hegel, men også i Kants Logik, betyr det at det er tale om en kategorisk enhet mellom to elementer. I utsagnet behandles disse elementer som subjekt og predikat. Vi står overfor en domsform, nærmere bestemt en kategorisk dom, som sammen med hypotetisk dom og disjunktiv dom danner den domstype Hegel kaller nødvendighetsdommer. Likheten mellom subjekt og predikat er nødvendig og substansiell, slik som f.eks. i dommen »A er B«, eller sagt med en empirisk variant,

2. Den følgende framstillingen av verdiformenes status er i alt vesentlig hentet fra undertegnedes skrift Kapitalbegrep-Begreps-begrep. To forutsetninger for den dialektiske logikk, Institutt for Filosofi, Oslo 1973. 
$»$ Gullet er et metall,«

Hvor gullet oppfattes som en del av mineralrikets substansielle (metalliske) natur. Sier jeg

$» 20$ alen lerret er verdt 1 frakk, «

taler jeg altså om et innhold som er enhetlig på en helt annen måte enn i dommen

$$
\text { »Gullet er gult, « }
$$

hvor enheten er tilfeldig, fordi fargen (predikatet) ikke sier noe substansielt eller nødvendig om tingen (arten), og heller ikke i seg selv kan oppfattes som et slektsprinsipp som opprettholder flere arter i en substansiell og nødvendig enhet. I Marx' uttrykk består den substansielle enhet i verdien, betraktet som en felles substans for subjekt og predikat. Uttrykket forteller oss at lerret og frakk er like forsåvidt som de er »verdier«. Men dette betyr at deres relasjon ikke bare er et kategorisk forhold, altså ikke bare et likhetsforhold, men også et »verdiforhold «, som Marx sier: »Frakken er bare det samme som lerretet såfremt begge er verdier« (Wf 265).

La oss nå holde fast ved at det som skal analyseres er formen i de setninger, utsagn, likninger, dommer vi har for oss. ${ }^{3}$ Hvilken form, hvilken strukturell betingelse, er det Marx her stiller opp for den kategoriske doms forekomst? Svaret er at den kategoriske form betinges av den hypotetiske domsform. Likhetsforholdet mellom lerret og frakk er verdiforhold, men ikke alle likhetsforhold er av verdimessig art. Lerret og frakk kan f.eks. tilfeldigvis være like både forsåvidt som de begge vurderes ut fra tyngdefenomenet overhodet, og forsåvidt som de faktisk også veier like mye. Men det er ikke denne likheten vi er ute etter. Vi er ikke opptatt med fysikk med utgangspunkt i gravitasjons- eller relativitetsteori. I Marx' »bare ... såfremt « ligger allerede et hypotetisk forhold gjemt. På samme måte er det hypotetiske domsuttrykket, f.eks. »Hvis gull, så metall«, eller, for å ta et eksempel som av bestemte grunner er langt bedre,

3. Marx' kjente bemerkning om at det ikke er underlig at $\varnothing$ konomene ikke har analysert verdiformene, når »profesjonelle logikere før Hegel « ikke engang unders $\varnothing$ kte forminnholdet i dommer og slutninger (E 274, note), er blitt særdeles dårlig forstått. Den innebærer at også den formen hans varelikninger presenteres $i$, må unders $ø$ kes kritisk av leseren. En slik kritisk lesing viser at verdiuttrykkene presenteres som et sett nødvendighetsdommer, noe som gir nøkkelen til forståelsen av kapitalens begrep slik Marx utvikler det i Kapitalen. Se videre Marx' bemerkninger om Wagners kritikk av Kapitalen, i MEW 19, s. 358: Han sier her at varen er et subjekt i hans framstilling, noe som sikkert betyr domssubjekt, og ikke umiddelbart et bevisst og handlende subjekt. 
noe som følger naturlig av den kategoriske dom med dens form »A er B.« Den er mao. en form som er nedlagt i den på forhånd, og som følgelig også begrenser dens rekkevidde og det felt av vitenskapelig erkjennelse den kan ha gyldighet i. I Marx' eksempel kommer dette til uttrykk i at den hypotetiske formen antyder analysens henvisthet til økonomiske gjenstander, og dens utelukkelse fra f.eks. en vitenskap som er basert på tyngdefenomener. Hegel mener den hypotetiske dom uttrykker at »A's væren (Sein) ikke er dens egen væren, men den andres væren, nemlig B's. « Eller mer presist uttrykt: »det endelige er riktignok sin egen væren, men like så mye ikke sin egen væren, men en annens væren « (L 2, 337). I den hypotetiske variant av det kategoriske verdiuttrykk er rammen gitt for hvordan begreper så som »fremtrædelse ... kan tilkendes en objektiv betydning inden for området af endelige, nemlig her $\varnothing$ konomiske »genstande « (Q 135). Vi skal nærme oss disse problemene gjennom å sitere Marx’ oppsummering av betydningsinnholdet i verdiuttrykkets dobbelte forhold:

»At lerretet forholder seg til frakken som sin like, eller at frakken, $i$ sin egenskap av å vare ting av samme substans, blir satt lik lerretet, uttrykker altså at frakken gjelder som verdi $i$ dette forholdet. Den blir satt lik lerretet, forsåvidt som også dette er verdi. Likhetsforholdet er altså verdiforhold, men verdiforholdet er først og fremst uttryk for verdien eller verdieksistensen (Wertsein) hos den varen som uttrykker sin verdi. Som bruksverdi eller varelegeme skiller lerretet seg fra frakken. Dens verdieksistens kommer derimot til syne, uttrykker seg, i et forhold, hvor en annen vareart, frakken, blir sat lik med den, eller gjelder som vesenslik med den« (Wf. 265-266).

Liksettingen av de to produktene er i sin helhet hypotetisk, for den forutsetter den usikre betingelse at de begge faktisk er, eller oppfattes som, verdier. Dette betyr at dommen, etter sin form, ikke »dømmer « om subjektets eller predikatets faktiske eksistens, men bare om deres innbyrdes relasjon såfremt de eksisterer. Hegel sier det slik: »Den hypotetiske dom inneholder bare den nødvendige relasjon, uten de relatertes umiddelbarhet « $(\mathrm{L} 2,395)$. Rent tilsynelatende mister den derfor sin karakter av å være en dom i streng betydning, og har »forsåvidt mer skikkelse av en setning « (L 2, 338). Det er da også utvilsomt det enkle verdiuttrykks hypotetiske karakter som er den viktigste grunn til at så mange kommentatorer ensidig søker til Hegels refleksjonslogikk for å begrunne vareanalysen. For i denne logikken, »Læren om Vesenet «, framstår dommene ennå ikke som dommer, men i høyden som setninger, så som »satsen « A = A, det Hegel kaller identitetssetningen. 
Og »identitet« og »differens « har, som nevnt, i følge ham sitt hjemsted i refleksjonen. Så lenge ikke hele denne sammenhengen tas i betraktning, blir en stående ved formuleringer som: »Vare-penge-likningen er den $\phi k o-$ nomiske opphevelse av identitetssetningen ${ }^{4}$ - teser som er mer fengende enn helt uttømmende.

At setninger som $\mathrm{A}=\mathrm{A}$ forekommer i refleksjonslogikken, er for $\emptyset \mathrm{v}$ rig en god illustrasjon av selve den uholdbarhet som leder denne logikken over i begrepslogikk: Det er jo nemlig umulig å operere med en ren tohet; selve skillet mellom de to, refleksjonen, »skinningen«, er i seg selv noe tredje. Men dette tredje foreligger her i en urealisert form; ordet »er« eller tegnet $»=«$ er her ikke å oppfatte som kopula (som er den filosofiske betegnelse på »er« i en dom), mener Hegel. Det er bare begynnelsen av en kopula, for når man sier at » $\mathrm{A}$ er «, så gjør man det med den forutanelse at noe forskjellig fra A skal utsies. Men dette forskjellige opptrer ikke (L 2, 44). Først i begrepets domsformer er differensieringen av innholdet kommet så langt at det enkeltstående (dommens subjekt) kan forenes med en allmenhet (predikat) og således framstå som en helhetlig, særegen ting. I følge Hegel uttrykker kopula, »er«, en trang til absolutt identitet mellom forskjellige elementer. Denne trang kommer til syne spesielt i nødvendighetsdommen, og dermed også i dens hypotetiske form. Men hvorfor framstår denne hypotetiske dom som om den bare var en »setning «?*

4. Hans-Georg Bacljais: »Zur Dialektik der Wertform«, i A. Schmidt (utg.): Beiträge zur marxistischen Erkenntnistheorie, Frankfurt am Main 1969, s. 142.

* For folk som er oppdratt med moderne »logisk« terminologi, kan det virke overflødig å skille mellom »dommer« og »setninger « i det hele tatt. En vil ha en tendens til å la dem alle falle inn under fellesbegrepet »setninger « eller »utsagn«. Dette har sin årsak i at borgerskapets autoriserte logikere etter Hegel har fortsatt den gamle tradisjonen med å se bort fra forminnholdet i dommene. Hver enkelt dom og hver enkelt domstype blir da oppfattet som stive og ubevegelige enheter, som kan analyseres hver for seg til evig tid. Overgangen mellom domstypene og domsformene, dvs. den dynamiske, overskridende faktor i menneskenes domfellelse, blir oversett. (Et eksempel på en slik dynamikk er overgangen mellom kategorisk og hypotetisk form, som vi nettopp har betraktet; et annet er overgangen fra disse formene til den disjunktive, som vi kommer tilbake til om et øyeblikk.) Det er som en følge av dette at »moderne « logikk ikke taler om dommer, men om »utsagn « - det Hegel ville kalle »setninger «. Hegel har det omvendte standpunkt av den »moderne teoriens. Hos ham er alle utsagn eller setninger egentlig dommer, i den forstand at de ikke kan stå på egne bein, uten å finne seg til rette i en større sammenheng. Når han sier at dét eller dét utsagn bare er en »ren setning « e.l., så mener han at det uttrykker et refleksjonslogisk standpunkt, hvor dets faktiske forbindelse med verden bevisst blir abstrahert bort.

Hegels terminologi, som vi for øvrig så konsekvent som mulig forsøker å følge i denne artikkelen, er slik at en dom kan oppfattes som (Hegel er ikke selv helt konsekvent i sin ordbruk) et uttrykk som dekker den og den konkrete domfellelse, f.eks. »Denne rosen er rød«, »Alle mennesker er dødelige«, »Rosen er en plante« eller »Den barmhjertige handling er god«. - Disse fire tilfellene er samtidig eksempler på det vi kan kalle hans domstyper eller arter av dommer, nemlig (i samme rekkefølge): Tilværensdommer (Eksistensdommer, Urteile des Daseins), Refleksjonsdommer (Urteile der Reflexion), Nødvendighetsdommer (Urteile der Notwendigkeit) og Begrepsdommer (Urteile des Begriffs). Hver av disse fire domstyper har i sin tur tre underklasser av dommer, som er det som her stort sett kalles domsformer. Den første deles i positive, negative og uendelige dommer (»Denne rosen er rød« er et noten fortsættes næste side 
Svaret ligger i at den kategoriske form ikke er preget av absolutt nødvendighet, fordi subjekt og predikat ikke uttømmer hverandre i sin forskjellighet. Rosen er riktignok en plante, men planten »er« ikke bare en rose, men også en mengde andre arter, som ikke nevnes i den konkrete dommen. Og når nødvendigheten ikke er absolutt, er den relativ og formell, og dette må framtre $i$ dommens form. Derfor får den en hypotetisk form: »Hvis $\mathrm{A}$, så $\mathrm{B}$, « eller »Hvis vare $\mathrm{A}$ (verdi), så vare $\mathrm{B}$ (verdi). «Denne formelle nødvendighet understreker dommens form og innebærer at den ikke kan bestemme fullstendig over sitt innhold. Men nødvendigheten virker desto sterkere når den først har fått begrenset sitt gyldighetsområde, på samme måte som et stempel først kan fungere skikkelig når det går langs vegger som slutter tett omkring det. I dette tilfellet framstår relasjonen mellom subjekt og predikat som noe altoverskyggende viktig. Men denne »relasjon « er intet annet enn det Tredje som ikke kommer til syne i refleksjonslogikken. Det toner fram for alvor i den hypotetiske dom, i Begrepets begynnelse.

Som både Kant og Hegel la vekt på, er den hypotetiske dom det begrepsmessige uttrykk for kausalitet: Hvis noe settes, følger noe bestemt annet med nødvendighet. Når vi nå ser at den, i form av »verdilikning «, får en minst like sentral plass hos Marx som hos hans forgjengere i det filosofiske felt, må vi vente å få lære noe vesentlig om kausalitetens stilling i samfunnsmessig praksis. Kanskje vil vi også få erfare at vi står overfor den samfunnsmessige genese til kausalitetstenkning og kausalt preget naturvitenskapelig tenkning overhodet.

Den hypotetiske form i det enkle verdiuttrykks verdiforhold kommer håndgripelig til syne $\mathrm{i}$ den vekt som ligger på subjektet, på lerretet. At frakken bare er som verdi forsåvidt som lerretet er det samme, kommer

eksempel på en positiv dom); den andre i singulære, partikulære og universelle (»Alle mennesker er dødelige « er av den universelle klassen); den tredje i kategoriske, hypotetiske og disjunktive (hvor »Rosen er en plante « er kategorisk), og den fjerde i assertoriske, problamatiske og apodiktiske (»Den barmhjertige handling er god « er apodiktisk).

Som en følge av skillet mellom »setning « og »dom« får verbformen »er«, som altså kalles dommens kopula, nemlig forbinderen av subjekt og predikat, betydning av å være et meningsinnhold, som varierer fra den ene domstype og domsform til den andre. (Selv om variasjonen ikke er større enn at kopula hele tiden må regnes som en enhet som streber etter identitet mellom subjekt og predikat.) Den er aldri det den gir seg ut for å være, - ikke det enkle »er« som den tilsynelatende er (og som den blir oppfattet som i »setninger«), men en konkret, sammensatt relasjon. I dommen »Gullet er et metall« består kopula altså av nфdvendighet. Den ytre formen »er« er sekundær, noe man kan se av at språk som latin og russisk, som i mange forbindelser ikke gjør bruk av former av verbet »å være«, kan få fram samme meningsinnhold med uttrykket »Gull metall«. (Et topppunkt av moderne logisk-filosofisk naivitet finner vi i Ludwig Wittgensteins verk Philosophische Untersuchungen, hvor forfatteren spør seg om russerne tenker seg kopula $i$ tillegg til et uttrykk som »Stein rød «! Som om ikke kopula nettopp er den forbindelse mellom en individuell sak (her: steinen) og allmen egenskap (her: rødhet) som gjør det mulig å tenke - for eksempel - en stein som noe rødt!) 
praktisk til uttrykk i at frakken bare er til stede som materielt substrat for lerretets trang til å vise verdien sin. Dette er kimen til det Marx kaller »varefetisj《 og »pengefetisj« $(\mathrm{K} 1,108)$. Den hypotetiske form uttrykker altså ikke bare kausalitet rett og slett, men en reell kausalitet som bevirker mystiske forestillinger om sin egen forklaringskraft.

\section{Totalt verdiuttrykk: Disjunktiv form}

La oss for oversiktens skyld allerede nå formulere den domsform som i følge Kant, Hegel og andre (f.eks. Bradley) er enheten av den kategoriske og den hypotetiske form, og som opphever en del av disses ufullstendigheter. Det dreier seg om den disjunktive. Formulert empirisk kan den f.eks. lyde

»Metallet er enten gull eller sølv eller bronse eller osv. $\ll^{5}$

men av grunner vi kommer tilbake til, eksemplifiseres den best med tre symboler, så som

»A er enten $\mathrm{B}$ eller $\mathrm{C} . \ll$

Hos Marx finner vi det »empiriske« eksemplet (E 232, jfr. K 1, 77) $» 20$ alen lerret $=1$ frakk eller $\mathrm{u}$ kaffe eller $\mathrm{x}$ jern eller

y hvete eller osv., osv.«

som formaliseres slik:

» $\mathrm{Z}$ vare $\mathrm{A}=\mathrm{u}$ vare $\mathrm{B}$ eller $\mathrm{v}$ vare $\mathrm{C}$ eller $\mathrm{w}$ vare $\mathrm{D}$ eller $\mathrm{x}$ vare $\mathrm{E}$ eller y vare F eller osv.«

Dette er den første utvikling av den enkle verdiform, og Marx kaller den »total eller utfoldet verdiform. «I Backhaus' skrift omtales den, også i tråd med Marx, som »form II «. Den beskrives langt grundigere og bedre i førsteutgaven av Kapitalen enn i annenutgaven. I sistnevnte utgave er hovedvekten lagt på at den som form er utilstrekkelig fordi rekken av mulige ekvivalenter for lerretet er uendelig og ikke definitiv. I førsteutgaven legger Marx minst like stor vekt på å beskrive den positivt og som en bestemt overskridelse av det enkle verdiuttrykk:

5. En merker seg at predikatet i eksemplet med den kategorisk-hypotetiske dom nå opptrer som subjekt. Ettersom vi her først og fremst er opptatt med dommens form, lar vi forklaringen av denne »omsnuingen« ligge. Vi kommer ganske detaljert inn på den i op.cit. 1973, s. 81-84. 
$» .$. denne annen form innebærer en vesentlig videreutvikling. Det ligger nemlig i den ikke bare at lerretet uttrykker sin verdi tilfeldig snart i frakker, snart i kaffe osv., men derimot at den uttrykker den såvel i frakker som i kaffe osv., enten i denne varen eller i hin eller i en tredje, osv.«(E 232)

Denne enhet-i-forskjellighet mellom prinsippene Såvel Som og Enten Eller er det klareste ytre kjennetegn på en disjunktiv dom, også for logikere som står langt fra Hegels dialektiske eller Kants »transcendentalfilosofiske« forståelse. I samme grad som denne beskrivelsen av verdiuttrykkets disjungerte form skyves bort fra scenen i Kapitalens annenutgave, må en si seg enig med Backhaus i at denne utgaven gir avkall på å framheve poenger som egentlig er uunnværlige for en vareanalyse.

Det sterkeste punkt i Backhaus' kritikk angår da også nettopp »form II «. Han peker på at »form III«, det Marx kaller den »allmenne verdiform«, blir utviklet på en helt annen måte i tillegget »Die Wertform « og i annenutgaven (Wf 281; K 1, 79) enn i førstekapitlet fra 1867. Denne »allmenne verdiform «, som i dette førstekapitlet heter »Tredje, omvendte eller resiproke annen form av den relative verdi, « kan oppstilles slik (Wf 281):

$$
\left.\begin{array}{ll}
1 \text { frakk } & = \\
10 \text { pund the } & = \\
40 \text { pund kaffe } & = \\
1 \text { quarter hvete } & = \\
2 \text { unser gull } & = \\
1 / 2 \text { tonn jern } & = \\
\mathrm{x} \text { vare A } & = \\
\text { osv. vare } & =
\end{array}\right\} 20 \text { alen lerret }
$$

Den er en følge av form II, eller ligger nedlagt i form II, eller (for å si det på enda en måte) »oppløser seg tilbakevisende (rückbezüglich) i form II « (K 1, 85), fordi den kan tolkes som en beskrivelse av situasjonen i form II sett fra de mulige ekvivalenters synsvinkel: de betrakter alle lerretet som ekvivalent.

Det er ingenting å innvende mot dette. Som Backhaus skarpsindig viser, er det imidlertid tvilsomt å gå direkte fra denne formen til pengeformen (Q 160), eller å oppfatte den nærmest som identisk med pengene, slik det skjer i annenutgavens 1. kapittel og $\mathrm{i} »$ Die Wertform « (Wf 286). I disse tekstene hevder Marx at lerretet i form III er utelukket (ausgeschlossen) fra den relative verdiform (plassen i likningenes venstreside) i kraft av en 
objektiv prosess fra de mange vareeiernes side. Denne objektive prosess »setter « lerretet som ekvivalentform. Det er mao. ikke noen tilfeldighet eller noe rent »subjektivt« at lerretet opptrer som ekvivalent i form III. Det eksisterer derfor, sier Marx, en avgjørende forskjell mellom formene II og III: I form II »utelukker « lerret-eieren hele kretsen av andre varer fra den relative verdiform, men denne utelukkelse kan være »en rent subjektiv prosess «, nemlig den prosess at »han beregner sin vares verdi i mange andre varer« (Wf 285, Q 160).

Såvidt vi forstår Backhaus, mener han at Marx illegitimt trekker inn det subjektive moment $i$ analysen av form II, som først og fremst er en objektiv form som har behov for å få sine immanente karaktertrekk gransket.

Nå finnes det hos Backhaus en viss tendens til å sette subjektive momenter opp mot »immanente « og objektive som om de skulle være $a b$ solutte motsetninger (Q 132, 141), mens det jo i virkeligheten er slik at et immanent mål under visse omstendigheter godt kan være subjektivt bevisst og samtidig bli brukt som ytre mål. Og ved analysen av varen er det ikke gitt på forhånd at en »subjektiv prosess« ikke er en viktig forklaringsfaktor.

I dette tilfellet må en likevel si seg enig med Backhaus. Det blir nemlig for vanskelig å forstå hvordan en objektiv prosess (i form III) skal kunne framstå som subjektiv så snart den ses fra den motsatte synsvinkel (i form II). I så fall er form III ikke lenger nedlagt i form II, slik Marx ikke desto mindre fortsetter å hevde i såvel »Die Wertform《som i annenutgaven av Kapitalen. For å popularisere stoffet gir han avkall på å framstille ikke bare overgangen fra form til form som en dialektisk bevegelse; han gir avkall på å framstille den forståelig i det hele tatt.

\section{4. »Vareformens selvopphevelse« (Q 160)}

I noen vanskelig tilgjengelige passasjer argumenterer Backhaus for at »Marx prisgiver ... den i første kapitel i førsteutgaven afgørende ledetanke, at med sin almengørelse må den anden form (form II) ophæves (aufheben) og dermed samtidig den tredie form (form III) for så vidt som denne nemlig overhovedet ikke kan være noget andet end den »reciprokke« anden form « (Q 159). La oss framstille hva Backhaus kan mene med dette, før vi går over til å fortolke det disjungerte verdiuttrykk, slik vi har møtt det i form II:

I første utgave av Kapitalens vareanalyse opererer Marx med en form IV, som framgår av en nøyere undersøkelse av form II. Form IV er på en måte et alternativt produkt av form II, ved siden av form III, og den består av en uendelig rekke disjungerte verdiuttrykk. 
»I sitt utfoldede relative verdiuttrykk (form II), som bare består av dens mange, enkle verdiuttrykk, opptrer lerretet ennå ikke som allmen ekvivalent. Snarere er det her ethvert annet varelegeme som er dets ekvivalent, som følgelig er umiddelbart byttelig med det, og som altså kan bytte plass med det« (E 239).

Forekomsten av denne umiddelbare byttelighet fører oss derfor til den fjerde form:

»20 alen lerret $=1$ frakk eller $=\mathrm{u}$ kaffe eller $=\mathrm{v}$ the eller $=\mathrm{x}$ jern osv; 1 frakk $=20$ alen lerret eller $=\mathrm{u}$ kaffe eller $=\mathrm{v}$ the eller $=\mathrm{x}$ jern osv; $\mathrm{u}$ kaffe $=20$ alen lerret eller $=1$ frakk eller $=\mathrm{v}$ the eller $=\mathrm{x}$ jern osv;

$$
\mathrm{v} \text { the }=\text { osv. } \ll
$$

Marx fortsetter:

»Men tilbakevisende (rückbezogen) gir hver av disse likningene frakk, kaffe, the osv. som allmen ekvivalent; de gir altså verdiuttrykket i frakk, kaffe, the osv. som allmen relativ verdiform for alle andre varer. Den allmenne ekvivalentform tilkommer alltid bare en vare, i motsetning til alle andre varer; men den tilkommer enhver vare i motsetning til alle andre. Men hvis enhver vare stiller sin egen naturalform framfor alle andre varer som allmen ekvivalentform, så utelukker alle varer alle fra den allmenne ekvivalentform, og dermed (utelukker de) seg selv fra den samfunnsmessig gyldige framstilling av sine verdistørrelser « (E 239-240).

For å se hvordan dette er det samme som »vareformens selvophævelse « (Q 160), kan vi sammenlikne det med en passasje i Kapitalens annet kapittel, »Bytteprosessen«, et kapittel som forble uforandret i annen utgave av verket, og som mao. bygger på det opprinnelige førstekapitlet. Det heter her:

»Ser vi nærmere etter, så gjelder enhver fremmed vare som særegen ekvivalent for enhver vareeiers egen vare; hans vare gjelder altså som allmen ekvivalent for alle andre varer. Men ettersom alle vareeiere gjør det samme, er ingen vare allmen ekvivalent, og varene har derfor heller ingen allmen relativ verdiform, hvor de setter seg like som verdier og sammenlikner seg som verdistørrelser. Følgelig står de overhodet ikke overfor hverandre som varer, men bare som produkter eller bruksverdier $\ll(\mathrm{K} \mathrm{1,101)}$.

At produktene ikke lenger framstår som varer, men nettopp som produkter, er »vareformens selvopphevelse«, i følge Backhaus. Han legger da også stor vekt på denne passasjen fra annet kapittel (Q 155). Passasjen 
utfyller den nettopp refererte argumentasjonen fra første kapittel, for ved å utelukke andre varer fra allmen ekvivalentform, utelukker en vare seg selv fra en allmen relativ verdiform, som bare er et annet uttrykk for den samfunnsmessig gyldige (les: allmen-gyldige) framstilling av dens verdistørrelse. Den samfunnsmessige utvikling av den allmenne ekvivalent går sammen med en tilsvarende utvikling av den relative verdiform. Er en ekvivalent virkelig allmengyldig, så er den det fordi alle andre varer så å si automatisk, uten innsigelser, inntar sine plasser i relativ verdiform og følgelig ikke lenger er umiddelbart byttelige mot hverandre, men bare mot pengene - en situasjon hvor form IV (med et betydningsfullt unntak, som vi kommer tilbake til) ikke lenger kan oppstå. Før pengene er utviklet logisk, går derimot varenes verdiuttrykk kontinuerlig »till grunne « i stadig nye uendelige rekker av disjunktive verdiuttrykk. En analyse av uttrykkenes objektive sammenheng viser altså at denne er for svakt utviklet til å kunne opprettholde seg. En kan i tråd med dette godt si at form II uttrykker en subjektiv prosess, men da må en si det samme ikke bare om form IV, men også om form III. Og det må argumenteres for at alle disse subjektive prosesser har et felles objektivt grunnlag.

Det eneste alternativ til å gå til grunne i disjunksjoner, er at den allmenne ekvivalent utvikles i pengeform, dvs. som edelmetall. Denne form kunne illustreres av at faktorene 2 unser gull og 20 alen lerret byttet plass i framstillingen av den »allmenne verdiform«, ovenfor. - »Selv om gull og sølv ikke er penger fra naturens side, er pengene av natur gull og sølv « (Z 131). Vi skal ikke her gå inn på årsakene til at den allmengyldige ekvivalent er knyttet til metalliske materialer, men snarere konsentrere oss om det terminologiske og logiske dilemma »vareformens selvopphevelse« bringer oss opp i, et dilemma som løses med pengeformen.

Dilemmaet uttrykker seg ved at vi på den ene siden utgår fra et verdiuttrykk som er framtredelsesform for varen, for så på den andre siden å ende opp i en konklusjon om at produktene ikke står i et slikt verdiuttrykk med hverandre: De står overfor hverandre bare som produkter. Motsetningen kan en forsøke å oppklare terminologisk ved å innføre kategorien »umiddelbart produktbytte «, slik Marx gjør det: »Det umiddelbare produktbytte har på den ene siden det enkle verdiuttrykks form, og har det på den andre siden allikevel ikke. Denne formen var x vare A - y vare B. Det umiddelbare produktbyttes form er: $\mathrm{x}$ bruksgjenstand $\mathrm{A}$ - $\mathrm{y}$ bruksgjenstand $\mathrm{B}$. Tingene A og B er her ikke varer før byttet, men blir det først gjennom byttet « $($ K 1, 102). Den manglende overensstemmelse mellom realitet og begrep løses gjennom handling, for handlingen er ikke absolutt bundet av tankens bestemmelser og krav til harmoni mellom seg selv og sin gjenstand. Det samme gjelder her som ved den samfunnsmessige hand- 
lingsrekke som til slutt utkrystalliserer gull og sølv som allmenne ekvivalenter: »I sin forlegenhet tenker våre vareeiere som Faust: I begynnelsen var handlingen. De har derfor handlet allerede før de har tenkt « $(\mathrm{K} 1,101)$, og setter i gang en serie produktbytter som så utvikler edelmetallene som allmen akvivalent. Men dette er en situasjon som ikke direkte angår den logiske framstilling i kapittel 1 av Kapitalens førsteutgave. Denne framstillingen forutsetter at produktene motsigelsesfritt kan kalles varer, dvs. fullt ut kan inngå i det enkle verdiuttrykks form, i motsetning til hva som er tilfellet med det umiddelbare produktbytte. Marx viser så at når varen på denne måten skal tenkes i en form (nemlig verdiuttrykkene) som er harmonisk med den selv, så går den ikke desto mindre til grunne hvis den ikke tenkes som ledd i en pengeøkonomi. Produktenes streben etter å bli varer (gjennom de umiddelbare produktbyttene) er derfor det samme som edelmetallets streben etter å bli penger. Det ene kan bare oppnås samtidig med det andre. I samme grad som vareanalysen allerede forutsetter pengene, kan en for øvrig si at den er å oppfatte som en del-analyse ikke bare av pengene, men også av kapitalen, for kapitalformen er pengenes adekvate form i Marx' framstilling. Sagt med andre ord: I Kapitalen opptrer varen bare som et kapitalprodukt. ${ }^{6}$

At Marx' opprinnelige intensjon har vært å framstille varen som en enhet med pengene kan en imidlertid få sikkerhet for allerede ved det faktum at vareanalysen er lagt fram som en serie domsformer. Med den klare tilknytning til dialektisk logisk tradisjon som Marx på samme tid påberoper seg, er det så godt som utenkelig at han skulle ha valgt denne framstillingsmåten uten å være seg bevisst at den forutsetter at et Tredje må virkeliggjøre seg overfor tohetens momenter - at altså selve framstillingsformen forutsetter ikke bare to varer eller to sider i et verdiuttrykk, men en tredje konkret enhet, nemlig pengene i metallskikkelse. Forsåvidt når Backhaus fram til korrekte konklusjoner ut fra et ufullendt bilde av Marx' metode. Forsøket på å beskrive en begrepssammenheng utelukkende med midler hentet fra refleksjonslogikk, kan være ansvarlig for at hans artikkel er spesielt lite leservennlig.

\section{Tolkning av det disjunktive verdiuttrykk}

Vi går nå over til å fortolke det disjungerte verdiuttrykk. Det kjennetegnes ved en potensielt uendelig rekke ekvivalenter, og er derfor det beste bevis på at den tohet som uttrykkes, og som uttrykkes ved noe tredje, nemlig ved likhetstegnet eller kopula'et »er verdt«, ikke forutsetter en empirisk tohet $\mathrm{i}$ betydningen »to ting «. Toheten kommer tvert om til syne ved den ene og

6. Jfr. Kapitalbegrep-Begrepsbegrep, s. 216. 
samme uendelige rekke av ting. Toheten ligger altså i og for seg verken i subjekt eller predikat, og må derfor ligge i kopula. Den er ikke en tallmessig tohet, men en deling av tanken i to motsatte former, i subjekt versus predikat, dvs. i relativ verdiform versus ekvivalentform. Kopula utelukker den vare som befinner seg i den ene form, fra den andre form. En vare må befinne seg enten i den ene form eller i den andre, uansett hvor mange andre varer den deler plass med. Likhetstegnet eller kopula spalter dem fra hverandre. Selve kopula, selve forholdet mellom subjekt og predikat, er derfor - innenfor vareanalysen (Marx) og nødvendighetsdommene (Hegel) - et disjungert forhold, et Enten Eller-forhold. Enhver dom er i seg selv en disjunksjon, og derfor kan en med full rett si at i den disjunktive dom er domsformen kommet på høyde med sitt eget begrep: Det som ligger i den på forhånd, blir nå åpent uttalt. Innholdsmessig sier den utfoldede verdiform noe om »empiriske« konkrete varer, om hva de er eller ikke er. Men det den etter sin form egentlig sier, er

»En vare er enten i relativ verdiform eller i ekvivalentform.«

Dette er så å si et »metauttrykk « om verdiuttrykket, og likhetstegn er ikke lenger påkrevd. I stedet trer en allminnelig kopula, »er«, men da i betydningen »er enten eller«. En ting er enten det ene eller det andre. Det er av slike grunner at dommen

$» \mathrm{~A}$ er enten $\mathrm{B}$ eller $\mathrm{C} \ll$

er det adekvate uttrykk for den disjunktive dom, som er et formuttrykk som ikke kan bli skikkelig referert gjennom aldri så gode empiriske eksempler. Derimot kan man tale om at forskjellige empiriske innhold på en god eller dårlig måte reflekterer det formen består i. Dommen »En vare er enten i relativ verdiform eller i ekvivalentform « reflekteres, men bare »dårlig « og indirekte, av den kategorisk/hypotetiske form » 20 alen lerret er 1 frakk verdt «, hvor subjekt og predikat former to poler. Den reflekteres derimot direkte av en annen disjunktiv dom, så som »20 alen lerret $=1$ frakk eller $\mathrm{u}$ kaffe eller $=\mathrm{v}$ the osv. « Men da reflekteres den godt ikke ganske enkelt fordi begge former er disjunktive. En slik tankegang ville innebære at en hefter seg ved rent ytre likhetstrekk, og så bort fra den immante, nødvendige enhet og likhet som på forhånd tenkes nedlagt i kopula. - Den reflekteres godt fordi det sistnevnte disjunktive uttrykk etter sin form kan tenkes som en bekreftelse av det som blir utsagt i det førstnevnte uttrykket. For det Marx har vist, er jo at form III ligger nedlagt i form II. I det disjunktive verdiuttrykk ligger det altså en form som kan sies å bekrefte det førstnevnte uttrykk med en nødvendighet som tilsvarer den form for 
objektiv sammenheng mellom subjekt og predikat som i vareanalyse og nødvendighetsdommer er tenkt inn i likhetstegn og kopula. Oppfatter vi nemlig form III slik Marx oppfatter den i »Die Wertform«, altså som en pengeform, så innebærer den jo at varene en gang for alle er plassert på én bestemt side av likhetstegnet. At deres posisjon i én form er deres negasjon i den andre, framstår derfor helt klart.

Men dette er altså også bare det som er tenkbart etter formen. Vi har nettopp sett at Marx kommer til uholdbare konklusjoner ved å legge all vekt på formelle forhold framfor på den objektive forbindelsen mellom subjekt og predikat. La oss se litt nærmere på hvilke forbindelser han legger vekt på i det opprinnelige førstekapitlet, og som han skyver i bakgrunnen såvel i »Die Wertform « som i annenutgaven.

I relasjonen »enten eller « er det som nevnt til stede et »såvel som«: Lerretet uttrykker sin verdi i alle andre varer. Den framstiller hele den $\emptyset$ vrige vareverden som hva vi kan kalle en positiv totalitet overfor seg selv; forsåvidt utelukker varene i ekvivalentformen ikke hverandre, men framstår rett og slett som et totalaggregat av varer. Det er dette »såvel som« som uttrykkes i form III, hvor det ved en omsnuing kommer til uttrykk hva som ligger nedlagt i form II. Sterkere kunne det vanskelig bli understreket at Backhaus har rett når han sier at form III »overhovedet ikke kan være noget andet « enn den tilbakebøyde form II. Form III er rett og slett totalitetsaspektet ved form II, forsåvidt som form II oppfattes som et disjunktivt uttrykk.

Det blir klarere hvilken blindgate som ligger i framstillingen $\mathrm{i} \gg$ Die Wertform «: Av form II, hvor lerret-subjektet står overfor en predikatenhet av »enten eller « og »såvel som«. Dette skjer i form av form III, men analysen av denne formen blir mildt sagt inadekvat fordi vi ikke engang skal vite at det faktisk er et slikt aspekt som blir undersøkt. Resultatet er at hele begreps- og domsstrukturen i vareanalysen blir tilslørt.

Dette har enda mer negative konsekvenser sett på bakgrunn av at framstillingen i førsteutgaven var spesielt skarpsindig og bygde opp verdiuttrykkene i en perfekt progresjon: Det var all grunn til å la den første oppstillingen av et disjunktivt uttryk bli fulgt av et uttrykk som framstilte prinsippet »såvel som «i en særskilt »dom«. For dette prinsippet er det tilgrunnliggende og vesentlige bak om forestillingen om et »enten eller«. Det er det »verdi-vesen « som dukket opp i det hypotetiske verdiuttrykk. Det er det felleslige for hele predikatets sfære, for alle ledd i predikatet. Skal det framstille seg særskilt, kan det derfor bare gjøre det i et uttrykk som unnlater å sette de predikative ledd opp mot hverandre. Dette kan bare skje når de snus om til venstre side av kopula. 
Vi har nevnt at den disjunksjon, det »enten eller«, som finnes mellom predikatets ledd, for Hegel egentlig er en disjunksjon mellom på den ene siden »prinsippet« Såvel Som, på den andre »prinsippet« Enten Eller. Dommen uttrykker altså først og fremst motsetningen mellom 1) artene oppfattet som en totalitet, som summen av arter; og 2) artene oppfattet som resultater av slektens produksjon. Denne »slekt « er subjektet i dommen. Den er ikke en empirisk slekt så som Metall, Kattedyr o.l., men selve begrepet om en slekt, vår måte å konstruere slektsbegreper på. Tilsvarende er leddene i predikatet ikke empiriske arter, men er vår måte å tenke »arter « på. Hegel mener nå at artsbegreper - tatt i denne spesielle og overordnede betydning - er produkter av slektstenkningen. De er særegne tanker, produkter av den tenkning som tenker begrepet »slekt«. Forstår vi denne strukturen, så forstår vi også den form, dvs. den tenkemåte, som ligger til grunn for at vi feller empiriske disjunktive dommer så som

»Metallet er enten gull eller sølv eller bronse eller platina eller osv. i det uendelige.«

I slike dommer er det umulig å si at slekten produserer artene: Vi kan ikke i slekten finne noe spesifiserende prinsipp som avgjør hvilke arter, og hvor mange, som finnes. Predikatets ledd kan fortsettes i det uendelige.

Det er annerledes med tenkningen oppfattet som slekt, eller med det logiske; for logisk inneholder dommen bare et begrep bestemt både som »såvel som« og som »enten eller«. Andre strukturelle trekk er det umulig å finne innenfor den - rent bortsett fra oppdelingen i subjekt, predikat og kopula. - Undersøker vi den disjunktive dom etter dens form, vet vi derfor på forhånd at vi har et subjekt som har evnen til å bestemme antallet »arter « og deres natur fullstendig. Dette subjekt er i følge Hegel den felles allmenhet, den nødvendige forbindelse, som dukket opp i den hypotetiske dom. Denne allmenhet er et begrep, og dette begrep beskrives i predikatet i den disjunktive dom. Det består av totalitet $o g$ av et spesifiserende prinsipp. Totaliteten er summen av arter (»såvel som «), mens det spesifiserende prinsipp, som kommer til syne i »enten eller«, produserer de arter som er mulige innenfor den og den bestemte slekt, en slekt der som nevnt er blitt avgrenset og definert i den hypotetiske domsform.

Nå har vi sett at hos Marx slår form III over i form IV, noe som innebærer at den kan beskrives gjennom form IV, og omvendt. Prinsippet »såvel som« går i sin tur »til grunne« i nye rekker av »enten eller«. Ikke bare er hver enkelt rekke uten ende; antallet rekker er det også. Som Marx sier i en annen forbindelse, må dette tyde på at den relative verdiform, eller domssubjektet, er »uferdig, fordi dens (dets) framstillingsrekke aldri tar slutt « (K 1, 78). Når han kan uttale seg slik om et disjunktivt uttrykk, må det 
innebære at han i likhet med Hegel mener at det i uttrykkets form ligger nedlagt en forutskikkelse av en subjekt-type som kan bestemme sine arters antall og prinsippet for deres produksjon. I likhet med Hegel kritiserer han altså vanlige disjunktive dommer for deres uendelige predikative rekker. Men han gjør det ikke ut fra Hegels teori om tenkningen, men ut fra en analyse av arbeidsprodukter som er satt inn i en særlig sosial sammenheng. Slike produkter har både et antall og et konstruksjonsprinsipp som vi erkejnner på en helt annen måte enn empiriske ting vi finner i naturen.

På denne historisk begrensede bakgrunn kan Marx gi uttrykk for at de stadig reproduserte uendelige rekker av gjensidig utelukkende ekvivalentvarer i seg selv gjør krav på å bli erstattet av ett enhetlig uttrykk. De må forstås i sitt begrep, og alt dette blir først mulig ved pengeformen. Pengeformen skiller seg fra form III ved at den ikke går tilbake i noen uendelig rekke av uttrykk. Den går imidlertid tilbake i ett disjunktivt uttrykk, nemlig »den allmenne ekvivalents spesifikke relative verdiform" (E 240) eller »ekvivalentvarens spesifikke relative verdiform « $(\mathrm{K} 1,83)$ en verdiform som faller sammen med $\gg$ den utfoldede relative verdiform eller form $\mathrm{II} \ll(\mathrm{K} 1,83)$.

Både pengeformen og den allmenne ekvivalent av formen III går altså tilbake på den disjunktive form. Men når form III tilbakebøyes i form II, er alle andre varer umiddelbart byttelige med den vare som i øyeblikket står i relativ verdiform, og følgelig blir rekken av disjunktive uttrykk potensielt uendelig. I pengeformen er det derimot bare én vare som har en slik umiddelbar byttelighet, og følgelig vil det bare stå ett disjunktivt uttrykk tilbake. Dette uttrykk, f.eks.

» 2 unser gull $=1$ frakk eller 10 pund the eller 40 pund kaffe eller 1 quarter hvete eller $=$ osv., «

er verdiuttrykket for den allmenne ekvivalentvaren i dens pengeform.

Selv i det høyeste utviklingstrinn verdiuttrykkene kan nå, går framstillingen av varen og pengene tilbake i et disjunktivt uttrykk. Pengene, dvs. hele vareverdenens objektive prosess for å utelukke en felles ekvivalentvare, lar seg bare begripe og beskrive når en slik uopphevelig domsform ligger til grunn.

Et nøyere studium vil vise at et avgjørende skille mellom Hegels og Marx' metoder kommer til syne her. Hos Hegel blir den disjunktive dom og dermed alle nødvendighetsdommene på en relativt uproblematisk måte »hevet opp« i en »begrepsdom « og deretter forvandlet til slutninger (syllogismer). - Også hos Marx finner det sted en overgang fra »dommer« til »slutninger«, eller rettere sagt fra relative verdiuttrykk til sirkulasjon. Denne overgang er muliggjort av pengevarens utvikling, som gjør det 
unødvendig og irrelevant å sammenlikne enkeltvarer. Varene måler sin verdi i gull, og deretter sirkuleres de av gullet, i bevegelsen vare-pengervare, eller V - P - V. Om denne formen sa Marx i 1859 at den »abstrakt logisk kan reduseres til slutningsformen S - A - E, hvor det særegne danner den første ekstremen, det allmenne den forenende (zusammenschliessende) midttermen, og det enkeltstående den siste ekstremen « $(\mathrm{Z}, 76)$. Vi skal ikke her gå mer inn på slutningenes struktur i Kapitalen, ${ }^{7}$ men snarere understreke at pengevarens henvisthet til et eget disjunktivt uttrykk innebærer at hele slutningssystemet, og den kapitalistiske produksjon som formelt sett ligger i kim i det, kontinuerlig er forankret i et domsforhold som det ikke kommer fri fra. I en slutning som V - P - V - S - A - E er midttermen, kjernen i syllogismen, selv utelukkende framstillbar i et disjunktivt uttrykk. Som penger uttrykker gullet det samfunnsmessige og abstrakte arbeid i naturalform: Det abstrakt-allmene arbeid foreligger som særegent arbeid, som det arbeid som gjøres i gullutvinning. Som sådant sirkulerer det varene. Men dets særegenhet gjør at det bare kan beskrives i et forhold overfor andre varer. Gullets disjunktive verdiuttrykk er denne beskrivelse og sammenlikning mellom særegne varer.

Når Marx utviklet form IV av form II, var det for å vise »vareformens selvopphevelse «, for å si det med Backhaus. Men denne »selvopphevelse « innebærer ikke noe mer dramatisk enn at varesløret trekkes til side slik at produktene kommer til syne som det de er: Konkrete enkeltresultater av det samfunnsmessige totalarbeid. Når Marx deretter går over til å analysere det han kaller »det umiddelbare produktbytte« og verdiformene slik de da framstår, kan han følgelig få fram at de i realiteten må forstås som former som det samfunnsmessige arbeid eksisterer i. Disse former er hva vi kan kalle delinger. De isolerer produkter fra andre produkter for å kunne få i stand rent kvantitative sammenlikninger. De deler opp den organiske helhet som det samfunnsmessige arbeid egentlig alltid er. De uttrykker arbeidsdeling og privateiendom til arbeidsmidler og materialer.

\section{Vareproduksjon og begrepsdannelse}

Hegel la en etymologisk betraktning til grunn for sin fortolkning av dommene. Dom heter på tysk Urteil. Det er vanlig å forstå dette som en benevnelse på en slags logisk »elementarpartikkel«, et uspaltelig atom, en opprinnelig del (»ursprünglicher Teil«), noe som viser hvordan en sak er delt, men som selv er udelelig. Denne forståelsen står kanskje ikke i radikal motstrid til Hegels, men han legger iallfall større vekt på å forstå

7. Vi har redegjort for den i op. cit. 1973, s. 106-122 og 130-148. 
dommen som en opprinnelig deling av noe opprinnelig ett og enhetlig: »en opprinnelig deling av det opprinnelig Ene.«Det »Ene« det er tale om, er i følge Hegel Begrepet (begrepsbegrepet) selv, og her kommer det til syne en avgjørende svakhet ved hans idealistiske metode: Begrepet »som sådant « eksisterer før dommene. Begrepets elementarformer, dommene, er noe som framgår av Begrepet selv. Av dette følger det vansker som Hegel på ingen måte klarer å løse. ${ }^{8}$

For vårt formål er det nyttig å sette Hegels svakhet i forbindelse med noen radikale standpunkter han utvikler i sin analyse av den disjunktive dom. Vi har nevnt at denne dommen på mange måter er innbegrepet av domsformene, forsåvidt nemlig som de alle innebærer disjunksjon. Hegel tolker nå dette slik at Begrepet ikke lenger bare kommer til syne som subjekt, men også som ett av sine egne disjunktive ledd (L 2, 342). For disse leddene er atskilt fra hverandre ved et Enten Eller som er det samme prinsipp som det som ligger i kopula. De er med andre ord blitt bestemt i forhold til sine omgivelser på samme måte som subjektet er blitt bestemt i forhold til sine. Følgelig framstår de selv som Begrep (subjekt i dommen). I den disjunktive dom framstår altså Begrepet som noe som er produsert av det selv.

Tanken om en slik selv-produksjon er på ingen måte absurd i og for seg. Men i den grad Hegel ikke klarer å sannsynliggjøre sin egen spesielle versjon av den, hva er da mer rimelig enn å si at Begrepet, menneskenes systematiske kunnskapsproduksjon, er noe som er framgått av et disjunktivt uttryk som er noe annet enn Begrepet? Hva er rimeligere enn å tenke seg at verdiuttrykkets disjunktive form produserer en virkelighet som har en slik struktur at den kan tilegnes begrepsmessig? ${ }^{9}$ At altså vare-pengerelasjonens framvekst skaper betingelsene for vitenskapelig erkjennelse i og av samfunn og natur? Verdiuttrykkets disjunktive form betyr jo i bunn og grunn at det er vareeierne selv som har tingliggjort sine bevisstheter, antatt vareform og gått inn i kategoriske, hypotetiske og disjunktive forhold til hverandre; de har disjungert seg selv, eller det kollektiv de selv utgjør, og dermed kan de erkjenne gjennom disjunksjon og gjennom de former (kategoriske, hypotetiske) som bygger opp disjunksjonen, samt gjennom de former disjunksjonen bygger opp.

Dommer er ikke opprinnelige delinger at et opprinnelig Begrep. De reflekterer derimot verdiuttrykk som fungerer som opprinnelige delinger av det samfunnsmessige arbeid, et arbeid som er den menneskelige erkjennelses totale form. I motsetning til hva Hegel mente, kan vi ikke få noe allment begrepp om tenkningen eller Begrepet før vi har vært i kontakt

8. Se Kapitalbegrep-Begrepsbegrep, s. 12.

9. Se Kapitalbegrep-Begrepsbegrep, s. 90. 
med empiriske arter. Men forefundne empiriske arter - av planter, metaller, dyr - gir oss ikke umiddelbart noen tilgang til det spesifiserende prinsipp vi må vite om for å erkjenne dem; og selv gir de oss vel ikke engang noen ledetråd til å erkjenne dem som arter i det hele tatt. Vår erkjennelse av dem - såvel som vår erkjennelse av vår egen tenkning overhodet - er formidlet av vår kontakt med en annen type empiriske »arter«, nemlig de vi selv har produsert. Disses historisk mest utviklede form har lenge vært vareformen. I erkjennelsen av disse »arter « og den totalitet de inngår i, har vi umiddelbar tilgang til det spesifiserende prinsipp: det ligger i det menneskelige arbeid.

En kan riktignok si at de varearter vi står overfor har et ubestemmelig antall og framstår i en tilsynelatende uendelig rekke. Men selve utviklingen av en pengevare viser at vi mestrer rekken, at vi kan produsere en oversikt der hvor den tilsynelatende må mangle: enhver ny vare lar seg underordne sitt slektsprinsipp i pengene. ${ }^{10}$ Pengene representerer i sin tur det samfunnsmessige arbeid og gir oss kontroll over artenes prinsipp, selv om det er en kontroll som framstår tilslørt og disjungert, og ikke i en klar og umiddelbar form, slik tilfellet vil bli i det kommunistiske vare- og pengeløse samfunn.

Tolker vi form IV som et singulært, disjunktivt uttrykk og ikke som en uendelig rekke, får vi »pengevarens spesifikke relative verdiform. «Den er den versjon av form som ikke faller sammen med »vareformens selvopphevelse«, men tvert om med dens allmenne forekomst. Sammen med den form som er komplementær med den, nemlig pengeformen, f.eks.:

$$
\left.\begin{array}{rl}
20 \text { alen lerret } & = \\
1 \text { frakk } & = \\
10 \text { pund the } & = \\
40 \text { pund kaffe } & = \\
1 \text { quarter hvete } & = \\
2 \text { unser gull } & = \\
1 / 2 \text { tonn jern } & = \\
\mathrm{x} \text { vare A } & = \\
\text { osv. vare } & =
\end{array}\right\} 2 \text { unser gull, }
$$

innebærer den at vareverdenen er blit endegyldig disjungert i relativ verdiform på den ene siden og ekvivalentform på den andre. Den

10. Dette gjelder for den allmenne ekvivalent i det hele tatt: »I form III, som er den resiproke annen form og altså er innbefattet i den, framstår lerretet ... som slektsformen (die Gattungsform) for ekvivalenten for alle andre varer. Det er som om dyret, den individuelle inkarnasjonen av hele dyreriket, eksisterte for seg ved siden av løver, tigre, harer og alle andre virkelige dyr, som i gruppert form danner dyrerikets forskjellige slekter, arter, underarter, familier osv.« (E 234) 
objektive sammenheng $o g$ disjunksjon mellom subjekt og predikat som forutsettes i den disjunktive domsform, har dermed fått sin tilsvarighet i virkeligheten.

Da Hegel undersøkte den disjunktive form, la han vekt på at en empirisk disjunktiv dom er uten nødvendighet fordi artenes antall og prinsipp er ubestemmelig. Dette betyr at prinsippet Enten Eller egentlig er fraværende $\mathrm{i}$ hans betydning: Sier jeg »puma «, så mener jeg $i k k e$ »huskatt «, ikke »øve«, ikke »tiger«. Een art utelukker altså riktignok en annen, men den utelukker ikke at det kan komme flere arter inn i den rekken den står i. Den bestemmer ikke hvor mange den kan utelukkes av. Men det motsatte ligger i Hegels versjon av Enten Eller: »Enten Eller utelukker enhver ytterligere (art) og former en total sfære i seg selv« (L 2, 340). Dette er den klareste forskjell mellom ren begrepsmessig og empirisk disjunksjon.

Verdiuttrykkene, de objektive domsforhold varene og vareeierne setter seg selv i, gir oss en rasjonell middelvei mellom disse to ekstremene. Det er gjennom sin egen objektive prosess at varene er kommet inn i pengeformen. Ved sin egen aktivitet er de kommet dit hen at de 1) utelukker enhver annen vare enn gullet (eller edelmetallet) fra rollen som allmen ekvivalent, og 2) dermed utelukker at en slik annen vare kan finne plass noe annet sted enn i relativ verdiform. De utelukker altså »enhver ytterligere«, i den forstand at de på forhånd har bestemt dens form, til tross for at vareartenes rekke er uendelig. Rettere sagt er de kommet fram til pengeformen fordi varenes rekke er uendelig.

Forsåvidt skaper varene en empirisk bevegelse som likner på den Hegel mener å finne i Begrepet. Men til gjengjeld gjør de det umulig for dette Begrepet å frigjøre seg fra sine lavere former. Idet det binder Begrepet og begrepsdannelsen til konkrete, konstruerte (ikke forefundne), men allikevel empiriske ting, setter de et disjunktivt uttrykk som betingelse for den. At det må bli slik, følger av at de samfunnsmessige forhold som de konstruerte ting inngår $\mathrm{i}$, må feste seg til disse tingene selv. De må i det minste feste seg i naturalformen til en ekvivalent for dem alle, og denne ekvivalenten må uttrykke sine forhold på en disjunktiv måte. Dette er bare et annet uttrykk for at de produkter den representerer, i virkeligheten er strukturert på en måte som er ekvivalent med den disjunktive.

\section{Konklusjoner}

En av de viktigste årsakene til den manglende forståelse av Marx' metode i Kapitalen er at verkets startpunkt har form av et hypotetisk uttrykk som lett forveksles med en refleksjonslogisk form. Dette standpunktet innebærer ikke noen nedvurdering av refleksjons-logiske faktorers be- 
tydning for vareanalysen. Tvert om, det setter slike faktorer inn i deres rette begrepsmessige sammenheng. For å ta et sentralt eksempel, nemlig undersøkelsen av varefetisjismen: Marx sier at den følger av at en vares ekvivalentfunksjon er som en »refleksjonsbestemmelse « fra en annen vares side; i det enkle verdiuttrykk er frakkens »ekvivalenteksistens (Aequivalentsein) så å si bare en lerretets refleksjonsbestemmelse (E 231). Denne terminologien har etter vår oppfatning klar bakgrunn i Hegels teori om illusjonen slik den legges fram i refleksjonslogikken. ${ }^{11}$ Men på samme måte som Hegel har en teori om at illusjonen kan stivne ytterligere til når Begrepets sfære er nådd, er den refleksjonsbestemmelsen Marx har i tankene, avhengig av begrepets bevegelse i den hypotetiske dom: Det er fordi frakken bare er som verdi hvis lerretet er det, at dens ekvivalentstatus virker som en refleksjon fra lerretet. Verdiforholdet understreker primært »verdieksistensen hos den varen som uttrykker sin verdi « (Wf 266), som vi har sett.

Forvekslingen mellom refleksjonslogikk og begrepslogikken i domsformene har fått desto mer negative følger fordi det hypotetiske uttrykk samtidig gir oss et middel til å begripe den formen for kausalitet Marx gjør bruk av. Samtidig avgrenser den Marx' økonomiske vitenskap overfor andre teorier og vitenskaper. Oppfatningen av Kapitalen som et arnested for refleksjonslogiske kategorier vil derfor lett føre til at grunnlaget for en virkelig vitenskapsteoretisk vurdering av Marx' verk forsvinner. Den kan dessuten lede til overilte parallellføringer mellom Marx og refleksjonsfilosofer som Kant, og er uforenbar med en seriøs undersøkelse av hva Marx har ment med »det rasjonelle i den metode Hegel oppdaget« (jfr. Q 117).

En slik undersøkelse vil være godt tjent med å begynne med en ideologikritikk av Logikkens vitenskap, og et av dens fornuftigste spørgsmål kunne være: Hvorfor tolker Hegel - som den første i filosofihistorien - dommens kopula som et identitetskrav? Er det urimelig å regne med at pengeøkonomiens revolusjonerende omseggripen, det stadig mer dominerende kravet om ekvivalens mellom økonomiske størrelser, var avgjørende? - Den som vil forkaste slike problemstillinger vil også være tilbøyelig til å overse hvilken bevisst vekt Logikkens vitenskap - i klar motsetning til f.eks. Kants Kritikk av den rene fornuft - legger på begreper som lar seg overføre til en $\emptyset$ konomisk sammenheng, dvs. til en beskrivelse av menneskenes materielle produksjon. Det er ikke bare Hegels begrep om teleologi, arbeidsmidler og - materialer som er aktuelt her. Hans begrep om »midtterm« (»medius terminus«) er mer omfangsrikt enn hans middelbegrep, og gir ham anledning

11. Se Kapitalbegrep-Begrepsbegrep, s. 24, 54. 
til å konstruere et system hvor alle subjektive og objektive krefter forener seg $i$ et sentrum, på samme måte som arbeid og natur i følge Marx subsumeres under kapitalen og forvrenges der. Det er relativt lett å parallellføre Hegels framstilling i læren om Begrepet med verdiuttrykk (dommer), sirkulasjon (syllogismer), verktøyproduksjon i manufakturen (teleologi) og kapitalistisk maskinproduksjon (absolutt idé). ${ }^{12}$ De $\varnothing$ konomiske kategoriers dominans i hans bevissthet er slående, selv om den er tilslørt og foreligger i en idealistisk form. Hvis man så i tillegg ikke lar det bli med å unders $ø$ ke paralleller mellom kategorier, men også aksepterer Hegels logiske unders $\emptyset$ kelser på deres egne premisser, kan man bare vanskelig godta at det skulle by på noe stort problem å anvende kategorier som har sitt opphav i »metafysikk«, på »endelige« $\varnothing$ konomiske gjenstander (jfr. Q 135). For som vi har sett av Hegels undersøkelse av den disjunktive form, må spørgsmålet snarere bli om ikke det såkalte $\emptyset$ konomiske felt og kategorisystem produserer de metafysiske problemstillingene. 